\title{
ПРОСВІТНИЦЬКА АГРОНОМІЧНА ДОПОМОГА СЕЛЯНАМ ПІВДНЯ УКРАЇНИ НА ПОЧАТКУ ХХ СТ.
}

Анотація: Стаття розкриває один з важливих аспектів реалізації Столипінської аграрної реформи на Півдні України - просвітнищьку агрономічну допомогу селянам, які перейшли до хутірського та відрубного господарства. Ця допомога проводилася у двох напрямках позашкільному поширенні сільськогосподарських знань серед дорослого населення та проведенні показових заходів. Питання сільськогосподарського просвітництва селян вирішувалися шляхом організації читань, бесід, влаштуванням сільськогосподарських курсів, а також проведенням екскурсій на зразкові поля та ділянки. Організащія показових заходів включала в себе створення мережі показових господарств, полів і ділянок. Встановлено, що проведені заходи з надання просвітнищької агрономічної допомоги селянам спонукали їх до застосування нових поліпшених прийомів ведення сільського господарства на власних ділянках.

Ключові слова: Південь України, Столипінська аграрна реформа, просвітнищька агрономічна допомога, показові поля і ділянки, земства

Модернізація сучасного сектора сільського господарства України вимагає постійного розвитку бізнесу та підприємницької діяльності, забезпечення сільської економіки ринкового типу кадрами високої кваліфікації, використання передового світового та вітчизняного досвіду на землі тощо. Удосконалення технологій у сільському господарстві неможливе без застосування інноваційних знань, умінь і компетенцій, які неможливо отримати у рамках базової вищої освіти. Подібні питання цікавили уряди та сільське населення України під час реформувань аграрного сектору економіки упродовж двох минулих сторіч. Одним з яскравих прикладів розвитку позашкільної сільськогосподарської освіти для дорослого населення є досвід Столипінської аграрної реформи, яка сьогодні знову придбала актуальність у зв'язку зі спробами перетворення сільськогосподарської галузі країни. При цьому на сучасному етапі особливої актуальності набувають регіональні дослідження. Вивчення історичного досвіду просвітницької агрономічної допомоги селянам Півдня України - одного з передових регіонів у реалізації аграрної реформи початку XX ст., сприятиме підвищенню потенціалу сучасних перетворень українського сільськогосподарського сектора.

Проблема розвитку сільськогосподарської освіти в Україні XIX - початку XX ст. набула достатнього вивчення у працях сучасних вітчизняних науковців К. Гавриленка 1 ,

\footnotetext{
* Міронова Ірина Сергіїва - доктор історичних наук, доцент кафедри історії Чорноморського національного університету імені Петра Могили (Миколаїв, Україна);

ORCID: https://orcid.org/0000-0002-3039-742X; e-mail: ya.Irina761@gmail.com

${ }^{1}$ Гавриленко K.M. Професійна аграрна підготовка у середніх навчальних закладах України кінця XIX початку XX ст. // Вісник Глухівського національного педагогічного університету імені Олександра Довженка.
} 
Н. Мірошниченко ${ }^{2}$, С. Горденко ${ }^{3}$, Ю. Берестеня ${ }^{4}$ й ін. Автори дослідили питання становлення та розвитку професійної аграрної підготовки у навчальних закладах України, в тому числі у німецьких колоніях південного регіону, проаналізували основні чинники та визначили етапи їі розвитку, висвітлили історію становлення державних і приватних сільськогосподарських навчальних закладів у зазначений період.

Натомість, в існуючій історико-економічній літературі питання просвітницької агрономічної допомоги селянам на Півдні України висвітлено побіжно, у зв'язку із загальними проблемами села на початку XX ст. Винятком є дисертаційне дослідження Я. Березняка ${ }^{5}$, окремі розділи якого присвячені освіті та просвітництву селян у Таврійській губернії в роки Столипінської аграрної реформи. Автор розкрив питання розвитку сільськогосподарських навчальних закладів і позашкільної сільськогосподарської освіти для дорослого населення, дослідив проблему поширення сільськогосподарських знань за допомогою бесід і читань, влаштування сільськогосподарських курсів, екскурсій на дослідні поля, станції та виставки у цій губернії. Дослідник дійшов висновку, що влаштування бесід і читань давало найбільш відчутні результати, оскільки дозволяло знаходити контакти 3 селянами та дізнаватись про головні потреби й проблеми населення 6 . Одночасно із цим слід відмітити, що у світлі вивчення просвітницької агрономічної допомоги селянам Півдня України, важливим є визначення основних напрямків цієї допомоги, особливості їі фінансування та виконання, обсяги та результати. Саме цей аспект і є метою нашого дослідження.

До початку XX ст. сільськогосподарська освіта в Україні мала свої традиції і певний контингент учнів, які поповнювали кадри агрономічної галузі. Столипінська аграрна реформа послужила потужним стимулом для подальшого розвитку сільськогосподарської освіти в Російській імперії. На урядову та громадську службу стягувалися по можливості всі особи, які мали сільськогосподарську підготовку, і все ж відчувалася величезна нестача в агрономічному персоналі. До того ж, при створенні індивідуальних хутірських та відрубних господарств, швидко зростав попит на сільськогосподарські знання й серед рядового землеробського населення. При таких умовах розширення старих і створення нових аграрних навчальних закладів стало справою державної ваги․

Згідно 3 новим «Положенням про сільськогосподарську освіту», прийнятим 26 травня 1904 р., всі сільськогосподарські навчальні заклади поділялися на вищі, середні і нижчі

Сер.: Педагогічні науки. 2016. Вип. 31. С. 243-253.

${ }^{2}$ Мірошниченко Н.О. Чинники та етапи розвитку сільськогосподарської освіти в Україні у XIX - на початку ХХ ст. // Сіверщина в історії України: Збірник наукових праць. 2015. Вип. 8. С. 234-236.

${ }^{3}$ Hordenko $S$. Leading trends of agricultural education development in the $19^{\text {th }}-$ at the beginning of the $20^{\text {th }}$ century. URL: http://ephsheir.phdpu.edu.ua:8081/xmlui/handle/8989898989/4526

${ }^{4}$ Берестень Ю. До питання про становлення сільськогосподарської середньо-професійної освіти в німецьких колоніях Півдня України на початку XX століття (на прикладі Ейгенфельдської сільськогосподарської школи) // Історія німців України. Матеріали всеукраїнської наукової конференції. Київ: ІПіЕНД ім. І.Ф. Кураса НАН України, 2017. С. 53-67.

${ }^{5}$ Березняк Я.В. Земські та урядові установи Таврійської губернії в сфері сільського господарства (18661914 рр.): дис... канд. іст. наук: 07.00.01. Миколаїв, 2017. 224 с.

${ }^{6}$ Ibid. C. 76.

${ }^{7}$ Давыдов М.А. Двадцать лет до Великой войны: российская модернизация Витте-Столыпина. СанктПетербург: Алетейя, 2016. С. 602. 
(початкові $)^{8}$. Початкові навчальні заклади поділялися на нижчі училища, нижчі школи 1-го і 2-го розрядів і практичні сільськогосподарські школи. Із початком Столипінської аграрної реформи до сільськогосподарських училищ почали висувати підвищені вимоги з підготовки фахівців для агрономічної служби. Із цією метою існуючі сільськогосподарські школи почали перетворювати на нижчі сільськогосподарські училища 9 .

На Півдні України початкову сільськогосподарську освіту в роки реформи селянські діти могли здобути у відповідних закладах трьох губерній регіону. Так, у Катеринославській губернії діти навчалися у Гнєдінській сільськогосподарській школі 1-го розряду ${ }^{10}$, Верхньодніпровській нижчій сільськогосподарській школі ${ }^{11}$ (у 1911 р. ці школи було перетворено на сільськогосподарські училища) ${ }^{12}$ та у П'ятихатській практичній сільськогосподарсько-ремісничій школі ${ }^{13}$. Початкову сільськогосподарську освіту в Херсонській губернії діти отримували у Новополтавській та Ямчитській (м. Кривий Ріг) сільськогосподарських школах ${ }^{14}$. У Таврійській губернії працювали Обіточинське нижче сільськогосподарське училище, Лук'янівська та німецька Ейгенфельдська нижчі сільськогосподарські школи ${ }^{15}$. За результатами перевірки Міністерства землеробства Ейгенфельдську школу було визнано найкращою серед навчальних закладів даного типу в Російській імперії. На момент іiі відкриття у 1907 p. вона була найсучаснішим багатопрофільним професійно-технічним навчальним закладом сільськогосподарської освіти Півдня України. До складу навчально-виробничого комплексу школи входили невелика ферма та власний парк сільськогосподарської техніки. у 1914 р. школу було перетворено на середній професійно-технічний навчальний заклад ${ }^{16}$.

Середні сільськогосподарські училища давали учням науково-практичну аграрну освіту для підготовки їх до сільськогосподарської діяльності ${ }^{17}$. у роки реформи на Півдні України були відкриті Верхньодніпровське земське середнє сільськогосподарське училище $(1911)^{18}$ і Землемірне училище $(1912)^{19}$ у Катеринославській губернії, Таврійське та

\footnotetext{
${ }^{8}$ Днепров Э.Д. Российское образование в XIX - начале XX века. Т. 2. Москва: Мариос, 2011. С. 437.

${ }^{9}$ Гавриленко К.М. Вказ. пр. С. 246.

${ }^{10}$ Адрес-календарь Екатеринославской губернии на 1910 год. / Под ред. Г.А. Богданова. Екатеринослав: ТипоЛитография Губернского Правления, 1910. С. 239.

${ }^{11}$ Верхнеднепровская низшая сельскохозяйственная школа // Памятная книжка Екатеринославской губернии на 1911 г. Екатеринослав: Типо-литография Губернского Правления, 1911. С. 143.

${ }^{12}$ Гнединское сельскохозяйственное училище 1 разряда // Памятная книжка Екатеринославской губернии на 1911 г. С. 115; Верхнеднепровское среднее сельскохозяйственное училище Екатеринославского губернского земства // Екатеринославский адрес-календарь. 1917 год. Екатеринослав: Губернская тип-фия, 1917. С. 296.

${ }^{13}$ Пятихатская практическая сельскохозяйственно-ремесленная школа Екатеринославского общества попечения о детях // Екатеринославский адрес-календарь. 1917 год. С. 296.

${ }^{14}$ Новополтавская сельскохозяйственная школа // Памятная книжка (Адрес-Календарь) Херсонской губернии на 1912 год. Херсон: Тип-фия Херсонского Губернского Правления, 1912. С. 52; Ямчитская сельскохозяйственная школа 1-го разряда // Памятная книжка (Адрес-Календарь) Херсонской губернии на 1912 год. С. 58.

${ }^{15}$ Березняк Я.В. Вказ. пр. С. 50-51.

${ }^{16}$ Берестень Ю. Вказ. пр. С. 56-65.

${ }^{17}$ Гавриленко К.М. Вказ. пр. С. 246.

${ }^{18}$ Давыдов М.А. Указ. соч. С. 603.

${ }^{19}$ Волков С.H. Высшее землеустроительное образование в России на пороге XXI века. URL: https://refdb.ru/look/2182353.html
} 
Євпаторійське сільськогосподарські училища (1914) - у Таврійській ${ }^{20}$, Одеське сільськогосподарсько-гідротехнічне училище (1915) - у Херсонській губернії ${ }^{21}$ Крім цих училищ у регіоні працювало Херсонське земське середнє сільськогосподарське училище, засноване $1874 \mathrm{p.}^{22}$

3 початком реформи виникла потреба у створенні більшої кількості училищ і шкіл садівництва. Із навчальних закладів цього типу в Катеринославській губернії відомою була Трипольська практична школа садівництва і виноградарства ${ }^{23}$. у Таврійській губернії ще 3 1868 р. працювало Нікітське училище садівництва та виноробства (м. Ялта) ${ }^{24}$, поблизу Сімферополя існувала Салгірська практична школа садівництва, виноградарства та виноробства ${ }^{25}$.

До початку реформи вища сільськогосподарська освіта на Півдні України була представлена Вищими курсами виноградарства i виноробства в Імператорському Нікітському саду. Цього було недостатньо і тому Головне управління землеустрою i землеробства (ГУЗі3) розробило, на основі проекту Катеринославської земської управи, план створення сільськогосподарського інституту в Катеринославській губернії, який, однак, не був реалізований ${ }^{26}$.

По закінченню початкових і середніх сільськогосподарських навчальних закладів випускники працювали нижчими агентами агрономічної організації на місцях завідуючими складами, агрономічними старостами, дільничними й іншими агрономами, інструкторами у державній і земських організаціях, управителями у приватних і казенних маєтках, вчителями народних шкіл, службовцями у кооперативах, кредитних товариствах тощо ${ }^{27}$. Вихованці цих навчальних закладів після їх закінчення лише у поодиноких випадках поверталися додому та не застосовували отримані знання на практиці у своїх господарствах, а реформаторам потрібно було досягти підвищення сільськогосподарських знань серед пересічного селянства задля поліпшення якості влаштування ними власного індивідуального господарства.

Реалізація головної мети Столипінської аграрної реформи - переведення селян на хутори та відруби - призвела до того, що з'явилася значна кількість індивідуальних господарств, які не мали рівних можливостей доступу до знань і умов для інновації. Ставлення до праці у більшості селян досить швидко змінювалося, але цього було недостатньо для досягнення головної господарсько-економічної мети перетворень радикального підвищення рівня селянського господарства, а значить і рівня його прибутковості. Необхідно було змінити якість селянської праці та підвищити врожайність. Так на порядок денний постали питання про надання агрономічної допомоги селянам i ліквідацію їх агрономічної неграмотності.

\footnotetext{
${ }^{20}$ Березняк Я.В. Вказ. пр. С. 60.

${ }^{21}$ Гавриленко К.М. Вказ. пр. С. 251.

${ }^{22}$ Херсонское земское среднее сельскохозяйственное училище имени императора Александра II // Памятная книжка Херсонской губернии на 1914 год. Херсон: Губернская Тип-фия, 1914. С. 71.

${ }^{23}$ Трипольская практическая школа садоводства и виноградарства // Екатеринославский адрес-календарь. 1917 год. С. 157.

${ }^{24}$ Гавриленко К.М. Вказ. пр. С. 250.

${ }^{25}$ Березняк Я.В. Вказ. пр. С. 50-51.

${ }^{26}$ Давыдов М.А. Указ. соч. С. 604-605.

${ }^{27}$ Гавриленко К.М. Вказ. пр. С. 251.
} 
Розглядаючи поставлене питання, варто зауважити, що селяни, в силу своєї традиційної психології, нелегко впускали у своє життя щось нове - перш за все це стосувалося сфери повсякденності, зокрема господарських звичок, прийомів тощо. Тому зусилля уряду та діячів агрономічної сфери були спрямовані на подолання недовіри селян до зміни звичного порядку ведення господарства. Головним було переконати їх у тому, що і вони зможуть вести господарство по-новому, і що їм це у кінцевому рахунку буде вигідно 28.

Початок агрономічної допомоги господарствам одноосібного володіння було покладено у 1908 р. Спочатку агрономічною допомогою в районах землеустрою керував Департамент державного земельного майна, а з 1911 р. - Департамент землеробства. Загальне керівництво цією роботою при губернських землевпорядних комісіях здійснювали Особливі агрономічні наради ${ }^{29}$. у 1908 р. була запроваджена посада завідувача агрономічною допомогою, до компетенції якого входило загальне керівництво цією сферою у губернії, розробка комплексу проблем агрономічної допомоги та контроль за ії реалізацією на місцях ${ }^{30}$. Зокрема, у Катеринославській губернії таку посаду займав інспектор сільського господарства М. Воронцов ${ }^{31}$. 31909 р. агрономічною допомогою на місцях займалися переважно земства ${ }^{32}$.

Для найбільш ефективного способу наближення агрономічної допомоги до сільського населення урядом було запроваджено дільничну агрономію, в результаті чого повіти були поділені на визначену кількість ділянок, у кожній з яких працював один агроном. Катеринославська та Херсонська губернії були губерніями з найбільш розвиненою дільничною агрономією, на які припадало у середньому по 68 агрономів ${ }^{33}$.

Дільнична агрономія стала свого роду локомотивом сільськогосподарської освіти селян. Біля місця проживання дільничних агрономів влаштовувалися агрономічні кабінети, при яких відкривалися сільськогосподарські бібліотеки й агрономічні музеі ${ }^{34}$.

Просвітницька агрономічна допомога була складовою частиною загальної агрономічної допомоги та включала в себе два основні напрямки діяльності: позашкільне поширення сільськогосподарських знань для дорослого населення і проведення показових заходів. Просвітницьку агрономічну допомогу селянам надавав уряд в особі ГУЗі3, земства та сільськогосподарські товариства.

Сільськогосподарське просвітництво селян проводилося за допомогою бесід, читань, короткочасних курсів та екскурсій на дослідні станції, показові господарства, поля та ділянки. Ще до початку реформи, 15 лютого 1903 р. імператор Микола II затвердив положення Кабінету міністрів «Про порядок проведення окремими особами, товариствами і суспільними організаціями народних читань по сільському господарству». Згідно 3 цим

\footnotetext{
${ }^{28}$ Давыдов М.А. Указ. соч. С. 519-520, 547, 602.

${ }^{29}$ Дауэнгауэр О.В. Правительственные организации и агрономическая помощь крестьянским хозяйствам в период аграрной реформы П.А. Столыпина (на материалах Тверской губернии) // Вестник ТвГУ. Серия «История». 2013. Вып. 3. С. 32-33.

${ }^{30}$ Давыдов М.А. Указ. соч. С. 533-534.

${ }^{31}$ Главное управление землеустройства и земледелия // Екатеринославский адрес-календарь. 1915 год. Екатеринослав: Губернская тип-фия, 1915. С. 208.

32 Землеустройство (1907-1910 гг.). Санкт-Петербург: Тип. В.Ф. Киршбаума, 1911. С. 61-63.

${ }_{33}^{33}$ Давыдов М.А. Указ. соч. С. 536, 538.

${ }^{34}$ Березняк Я.В. Вказ. пр. С. 66-67, 74.
} 
документом, читання могли здійснюватися по друкованим текстам або усно за затвердженою програмою. Фінансувати читання мали суспільні організації, повітові земства та Департамент землеробства ${ }^{35}$. Узагалі, якщо говорити про фінансування позашкільної сільськогосподарської освіти на Півдні України, то воно було мізерно малим, що можна побачити за даними у таблиці 1.

Таблиця 1

Фінансування позашкільної сільськогосподарської освіти на Півдні України у 1908-1910 рр. (у руб.)

\begin{tabular}{|l|c|c|c|}
\hline \multicolumn{1}{|c|}{ Губернія } & $\begin{array}{c}\text { Курси, читання, бесіди, } \\
\text { книги, брошури }\end{array}$ & $\begin{array}{c}\text { Виставки і } \\
\text { музеї }\end{array}$ & $\begin{array}{c}\text { Усього на організацію } \\
\text { агрономічної допомоги }\end{array}$ \\
\hline Катеринославська & 3400 & - & 81655 \\
\hline Херсонська & 2425 & 600 & 159208 \\
\hline Таврійська & - & - & 91160 \\
\hline Разом & 5825 & 600 & 332023 \\
\hline
\end{tabular}

Якщо на організацію усієї агрономічної допомоги в регіоні у 1908-1910 рр. було виділено понад 332 тис. руб., то, як бачимо, на просвітництво селян - у п'ятдесят разів менше. На просвітницьку роботу в Таврійській губернії у ці роки кошти взагалі не передбачалися. Тому весь тягар фінансування лягав на плечі земств і сільськогосподарських товариств.

Поліпшення загальних умов агрономічної роботи в селах у наступні роки сприяло тому, що позашкільне поширення сільськогосподарських знань збільшувалося і напередодні Першої світової війни стало одним з головних компонентів просвітницької агрономічної допомоги. В Україні лідерами у цій справі були південні губернії. Так, в 1913 р. у Катеринославській губернії було проведено 629 читань і бесід, загальна кількість відвідувачів на яких досягла 24,5 тис. ${ }^{37}$ У Херсонській губернії кількість читань дорівнювала близько 450, а кількість слухачів коливалася від 25 до 50 тис. ${ }^{38}$ у Таврійській губернії було проведено 853 бесід і читань, які відвідали близько 55 тис. чол. ${ }^{39}$

Програмою були передбачені такі теми для бесід і читань: про переваги хутірського та відрубного господарства; грунт і його обробіток; боротьба на полях з бур'янами й іншими шкідниками; сівозміни; правила культивування пшениці, жита, ячменю, кукурудзи; посівні кормові рослини; розвиток тваринництва тощо. Як вказує Я. Березняк, ці бесіди для агрономів стали прекрасним засобом ознайомлення 3 потребами місцевих господарств, а 3 іншої сторони - були найбільш зручним способом подачі порад і пояснень по різних господарських питаннях. Проводились такі заходи переважно взимку, а також у святкові та вихідні дні, часто супроводжуючись показами агрономів картин за допомогою «чарівного

\footnotetext{
${ }^{35}$ Ibid. C. 65-66.

${ }^{36}$ Складено та підраховано за: Землеустройство (1907-1910 гг.). С. 88-95.

${ }^{37}$ Ход крестьянского дела // Екатеринославский адрес-календарь. 1915 год. С. 87.

${ }^{38}$ Давыдов М.А. Указ. соч. С. 540-542.

${ }^{39}$ Березняк Я.В. Вказ. пр. С. 67.
} 
ліхтаря» (проектора 3 діапозитивами), зразків насіння, шкідників та інших наочних посібників ${ }^{40}$.

Спочатку до порад і вказівок на читаннях більшість селян ставилися недовірливо: бентежило те, що невідомо чому з'явилася людина, що називала себе агрономом, який тепер приїжджав повідомляти, як треба вести сільське господарство. Наприклад, у звіті за 1911 р. агроном землевпорядної комісії Бахмутського повіту Катеринославської губернії П. Алекторов, розповідаючи про свою роботу, відзначав, що «в масі слухачів були особи, що ставилися надзвичайно недовірливо як до агронома, так і до всього того, що пропонувалося і говорилося їм, були, навпаки, й особи, які мали бажання поставити у себе той чи інший досвід» ${ }^{41}$. Але, як видно зі звіту Катеринославського губернського земства за той же рік, просвітницькі агрономічні заходи в більшості зустрічали у населення величезний інтерес, а читання та бесіди завжди збирали велику кількість слухачів ${ }^{42}$.

Зі зміцненням агрономічної організації виникли нові методи просвітницької роботи - організація короткострокових курсів (один-два тижні), метою яких було дати посилену підготовку селянам, які могли стати провідниками сільськогосподарських знань у село. Організовувалися курси зазвичай повітовими землевпорядними комісіями спільно із земствами, на яких фахівці викладали основи сільськогосподарських знань ${ }^{43}$. Охочих побувати на курсах було багато, тому повітові земства часто за власний рахунок створювали ïх на базі місцевих установ. Так, 27 лютого 1911 р. у Сергіївській церковно-приходській школі Великого Токмаку Бердянського повіту Таврійської губернії за ініціативою місцевого земства відкрилися двотижневі сільськогосподарські курси для селян, які відвідали 167 чол. $^{44}$

Крім курсів, земства проводили і спеціальні екскурсії на дослідні поля, станції та виставки, показові ділянки у сади, які теоретично були кориснішими та наглядно демонстрували новітні агрономічні досягнення. У цьому контексті варто відзначити Дніпровське повітове земство, яке з 1910 р. щорічно фінансувало екскурсії селян до Херсонської дослідної станції ${ }^{45}$. у Катеринославській губернії в 1913 р. земствами було проведено 33 курсів, 11 екскурсій і 30 виставок ${ }^{46}$.

Крім земств, просвітницьку агрономічну допомогу на Півдні України надавали сільськогосподарські товариства, які були покликані показувати селянам живий приклад нового життя. У цій справі вони мали: поширювати теоретичні та практичні відомості по сільському господарству шляхом влаштування публічних читань, друкування та розповсюдження власних праць і періодичних журналів; засновувати дослідні станції, поля, ферми, сади і розплідники; сприяти селянам у правильній організації їхніх господарств корисними вказівками; влаштовувати виставки тощо. Законодавство трактувало ці товариства як установи, що поєднували в собі практичну діяльність з підйому сільського

\footnotetext{
${ }^{40}$ Ibid. C. 65-66, 68.

${ }^{41}$ Давыдов М.А. Указ. соч. С. 548-550.

${ }^{42}$ Ход крестьянского дела // Адрес-календарь и памятная книжка Екатеринославской губернии на 1912 год. Екатеринослав: Тип-фия Губернского Правления, 1912. С. 21-22.

${ }^{43}$ Дауэнгауэр О.В. Указ. соч. С. 35-36.

${ }^{44}$ Березняк Я.В. Вказ. пр. С. 63-64.

${ }^{45}$ Ibid. C. 64-65.

${ }^{46}$ Ход крестьянского дела // Екатеринославский адрес-календарь. 1915 год. С. 87.
} 
господарства країни з просвітницькою.

У період 1905-1914 рр. в Російській імперії було відкрито 3365 сільськогосподарських товариств, із них на Півдні України було засновано: у Катеринославській губернії - 98 товариств, Херсонській - 87, Таврійській - 39. Станом на 1 січня 1915 р. Катеринославська і Херсонська губернії були віднесені до губерній-лідерів за кількістю товариств ${ }^{47}$.

Найбільшим на Півдні України було Імператорське товариство сільського господарства Південної Росії (м. Одеса), яке мало у своєму складі п'ять комітетів: виноградарства (очолював князь П. Трубецькой); шовківництва (В. Бертенсон); дослідного поля (М. Сухомлінов); сільськогосподарської економіки і статистики (Є.Стефанов); лісівництва (О. Гельд). Президентом ради товариства був М.Сухомлінов ${ }^{48}$. у період Столипінської аграрної реформи товариство стало першим на Півдні України ініціатором 3 організації у 1912 р. практичних курсів для агрономічного персоналу. У цей період діяльності товариства були закладені основи генетико-селекційного інституту, Одеської крайової сільськогосподарської станції. Його члени сприяли утворенню кафедр університету, організації сільськогосподарського інституту, який був відкритий 1917 р. в Одесі ${ }^{49}$.

у Катеринославській губернії плідно працювало Катеринославське сільськогосподарське товариство, яке очолював князь М. Урусов. Окремо існували галузеві товариства. Так, Катеринославський відділ імператорського російського товариства сільськогосподарського птахівництва займався масовим поліпшенням птахівництва в губернії, задля чого поширював корисні відомості з птахівництва, продавав і роздавав селянам племінну породисту птицю, влаштовував у Катеринославі виставки птахівництва. Почесним головою товариства був камергер двору В. Гончаров, головою відділу М. Папчинський. Катеринославський відділ імператорського російського товариства садівництва, який очолював катеринославський губернатор В. Колобов, займався організацією садових розплідників і садів при народних школах, звідки селяни отримували посадковий матеріал для їх вирощування на своїх садибах. При цьому вчителі проводили 3 селянами бесіди, під час яких пояснювали основні правила по догляду за деревами ${ }^{50}$. Катеринославський відділ імператорського російського товариства плодівництва регулярно проводив виставки-ярмарки плодівництва та городництва (головою відділу був Е. Бродський) ${ }^{51}$. Поліпшенням у губернії бджільництва і поширенням знань 3 цієї галузі серед селян займалися Катеринославське товариство бджільництва (голова П. Кумов), Запорізьке товариство бджільництва (голова Я.Новицький) і Кінсько-Роздорське

\footnotetext{
${ }^{47}$ Давыдов М.А. Указ. соч. С. 610-612, 618-619, 621.

48 Императорское общество сельского хозяйства Южной России // Памятная книжка Херсонской губернии на 1911 год. Херсон: Тип-фия Херсонского Губернского Правления, 1911. С. 146.

${ }^{49}$ Мезенцева И.Н. Роль общества сельского хозяйства Южной России в общественном развитии региона в ХIX - начале XX вв. // Юг России: реформы, революции, поиски гражданского мира (памяти П.А. Столыпина): Материалы Региональной научной конференции / Отв. ред. Г.Г. Матишов. Ростов-на-Дону: Изд-во ЮНЦ PAH, 2011. C. 88.

${ }^{50}$ Обзор Екатеринославской губернии. Краткие статистические сведения 1914 года // Екатеринославский адрес-календарь. 1915 год. С. 69.

${ }^{51}$ Разные общества, кассы, союзы и артели // Екатеринославский адрес-календарь. 1915 год. С. 239-240.
} 
товариство бджільництва (голова М. Колесніченко) ${ }^{52}$.

Для сприяння розвитку сільського господарства на Півдні України товариства ще до початку реформи почали видавати свої галузеві журнали. Так, Імператорське товариство сільського господарства Південної Росії видавало журнал «Записки императорского общества сельского хозяйства Южной России», в якому друкувалися спеціальні керівництва з садівництва, виноградарства, вівчарства, травосіяння тощо. Свої періодичні видання мали й окремі комітети товариства. Зокрема, комітет виноградарства видавав «Труды комитета виноградарства», окремими випусками друкувалися «Труды комитета шелководства»,

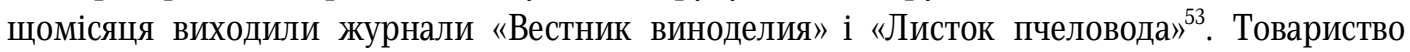
також надавало сторінки «Записок» для публікації наукових результатів, отриманих Плотнянською дослідною станцією, херсонським та одеським дослідними полями ${ }^{54}$. Також у Катеринославській губернії видавалися журнали «Южное хозяйство» і «Пчела $»^{55}$, у Таврійській губернії - «Фермер» і «Записки Симферопольского отдела Императорского Русского общества садоводства $\aleph^{56}$.

Окрім підвищення сільськогосподарських знань селян, у період реформи перед урядом, землевпорядними установами та земствами постало завдання ознайомити селян із новітніми способами забезпечення високої урожайності полів і відповідної продуктивності тваринницької галузі, показати заходи, які $б$ на живому прикладі довели селянину можливість і вигідність застосування на своїй ділянці поліпшених прийомів рільництва. Іншого варіанту, крім максимально можливого наближення агрономії до селянських полів, крім «демонстрації на місцевості», не було ${ }^{57}$.

Варто зазначити, що показові заходи не були новизною Столипінської аграрної реформи. Катеринославське і Херсонське земства ще у 1890-х рр. почали створювати мережу показових полів і ділянок, які розглядалися як форпости агрокультури. У цей період агрономів хвилювали такі проблеми, як наявність на показових полях сільгоспмашин $\mathrm{i}$ знарядь, які допомогли б на власні очі демонструвати селянам поліпшені і правильні прийоми обробки грунту.

Практика встановила три типи показових заходів - показові господарства, показові поля та показові ділянки. Показове господарство повинно було демонструвати найкраще поєднання окремих галузей господарства, показові поля - вигоди введення багатопільних сівозмін і застосування інтенсивних прийомів землеробської техніки, показові ділянки окремі поліпшені прийоми рільництва ${ }^{58}$.

До 1910 р. на Півдні України було створено п'ять показових господарств, 298 показових полів, 1554 показових ділянок (див. Табл. 2). Розподілялися вони, як можна побачити з наведеної таблиці, нерівномірно. Лідирувала у проведенні цих заходів Катеринославська губернія.

\footnotetext{
${ }^{52}$ Общества пчеловодства // Екатеринославский адрес-календарь. 1915 год. С. 239, 301.

${ }^{53}$ Периодические издания г. Одессы // Памятная книжка (Адрес-календарь) Херсонской губернии на 1912 год. C. 148

${ }^{54}$ Мезенцева И.Н. Указ. соч. С. 88.

${ }^{55}$ Периодические издания // Екатеринославский адрес-календарь. 1915 год. С. 247.

${ }^{56}$ Березняк Я.В. Вказ. пр. С. 74.

${ }^{57}$ Землеустройство (1907-1910 гг.). С. 63-64.

${ }^{58}$ Давыдов М.А. Указ. соч. С. 542-543.
} 
Таблиця 2

Показові заходи 3 просвітницької агрономічної допомоги на Півдні України (1910р.) $)^{59}$

\begin{tabular}{|l|c|c|c|}
\hline \multicolumn{1}{|c|}{ Губернія } & Показових господарств & Показових полів & Показових ділянок \\
\hline Катеринославська & 1 & 51 & 1007 \\
\hline Херсонська & - & 223 & 437 \\
\hline Таврійська & 4 & 24 & 110 \\
\hline Разом & 5 & 298 & 1554 \\
\hline
\end{tabular}

На кінець 1913 р. у Катеринославській губернії функціонувало вже три показових господарства, 143 показових поля і 2789 показових ділянок. До того ж, у справі розвитку та поліпшення спеціальних галузей сільського господарства, земствами організовано 25 показових садів, 4 показових городи, 16 показових пасік, 1 виноградник і 6 плодових розплідників ${ }^{60}$.

До завдань просвітницької агрономічної допомоги входила також організація дослідного господарства. Дослідну ділянку влаштовували на землі, відведеній для агрономічного центру, а показові господарства закладалися на прилеглих селянських землях. Посіви та худоба показового господарства підлягали страхуванню, за що з власника щорічно стягувався певний грошовий внесок. Біля кожного показового хутора закладалися групи показових ділянок незначного розміру, які, зазвичай, не перевищували у середньому однієї десятини. Ці ділянки мали демонструвати селянам поліпшені землеробські прийоми та заохочувати їх до введення таких у власних господарствах ${ }^{61}$. На показових ділянках селяни знайомилися з такими методами обробки грунту та посіву, як рання оранка й осіння оранка, подвійна оранка, коткування, рядовий посів, застосування добрив тощо $0^{62}$.

Таблиця 3

Порівняння врожаїв на показових і звичайних селянських полях Херсонської губернії у пудах (1910 р.) $)^{63}$

\begin{tabular}{|l|c|c|c|c|}
\hline \multirow{2}{*}{\multicolumn{1}{c|}{ Культура }} & \multicolumn{2}{|c|}{ На показових полях } & \multicolumn{2}{c|}{$\begin{array}{c}\text { У звичайних селянських } \\
\text { господарствах }\end{array}$} \\
\cline { 2 - 5 } & Середній & Вищий & Середній & Вищий \\
\hline Озиме жито & 113 & 164 & 55 & 105 \\
\hline Озима пшениця & 114 & 177 & 55 & 130 \\
\hline Яра пшениця & 49 & 105 & 30 & 55 \\
\hline Ячмінь & 98 & 209 & 75 & 122 \\
\hline Овес & 113 & 180 & 84 & 130 \\
\hline Кукурудза & 168 & 288 & 140 & 225 \\
\hline
\end{tabular}

\footnotetext{
${ }^{59}$ Складено та підраховано за: Землеустройство (1907-1910 гг.). С. 84-87.

${ }^{60}$ Ход крестьянского дела // Екатеринославский адрес-календарь. 1915 год. С. 87.

61 Землеустройство (1907-1910 гг.). С. 71-72.

62 Давыдов М.А. Указ. соч. С. 543.

${ }^{63}$ Складено та підраховано за: Землеустройство (1907-1910 гг.). С. 81.
} 
у результаті, наочний приклад значного підвищення прибутковості землі, досягнутий в умовах середнього селянського господарства, усував сумніви селян у вигідності нових форм землекористування. У тих губерніях, де робота 3 влаштування показових господарств і полів почалася ще до початку реформи, відчутним було бажання селян перейти до більш інтенсивної культури землеробства. До числа таких українських губерній відносилися Київська та Херсонська ${ }^{64}$. Зокрема, за даними, отриманими з 29 груп показових полів Херсонської губернії, відносна врожайність цих полів і звичайних селянських господарств була представлена в такому вигляді (див. Табл. 3). Як можна побачити 3 таблиці, урожай сільськогосподарських культур на показових полях перевищував урожай сусідніх звичайних селянських полів у півтори-два рази.

Підвищення врожаїв, досягнуті на показових полях і ділянках, спонукали селян до застосування нових прийомів землеробської техніки, а також до поширення травосіяння і нових культур. На території Півдня України налічувалася значна кількість господарств, які почали практикувати нові сівозміни, зокрема відбувався поступовий перехід від перелогової системи до багатопільно-трав'яної, покращеної зернової і промислової. у Херсонській губернії почало швидко розвиватися травосіяння завдяки діяльності місцевих земств, які організували в губернії показові поля і роздавали селянам посівне насіння трав. Завдяки цьому в губернії набули поширення такі трави, як могар, люцерна та еспарцет ${ }^{65}$.

у Катеринославській губернії багато селян звернули увагу на розвиток виноградарства i, завдяки проведеним дослідам по удосконаленню культури винограду, почали розводити його у своїх садибах. 3 часу виникнення в народних школах зразкових вчительських пасік з удосконаленими вуликами і посівами медоносних рослин, у губернії почало відроджуватися бджільництво. Великого розвитку воно отримало в Слов'яносербському та Катеринославському повітах ${ }^{66}$. При організації показових ділянок селяни почали проявляти інтерес й до нового інвентарю для обробки грунту. У цей час почали користуватися попитом гвинтові плуги, дискові борони, окучники ${ }^{67}$.

За період проведення Столипінської аграрної реформи Комітетом по землевпорядних справах на агрономічну допомогу селянським господарствам було надано близько 30 млн. руб., але 3 цих коштів на організацію показових заходів було виділено всього 2 млн. 287 тис. руб., за рахунок яких земствами та землевпорядними комісіями було організовано 1100 показових господарств, 10200 показових полів і близько 106 тис. показових ділянок у всій Російській імперії. При цьому слід зазначити, що у перші роки проведення реформи на показові заходи тим селянським господарствам, які погоджувалися здійснити на своїх ділянках пропоновані нововведення, надавалися значні пільги. Але в 1912 р., через нестачу коштів, Комітетом було встановлено межу витрат на організацію показового господарства у розмірі 200 руб., показового поля - 100 руб. і показової ділянки

\footnotetext{
64 Землеустройство (1907-1910 гг.). С. 74-75.

${ }^{65}$ Россия. Полное географическое описание нашего отечества. Настольная и дорожная книга. T. XIV. Новороссия и Крым / Под ред. В.П. Семенова-Тян-Шанского. Санкт-Петербург: Издание А.Ф. Девриена, 1910. C. 274-275.

${ }^{66}$ Обзор Екатеринославской губернии. Краткие статистические сведения 1914 года // Екатеринославский адрес-календарь. 1915 год. С. 69.

${ }^{67}$ Дауэнгауэр О.В. Указ. соч. С. 33.
} 
- 25 руб., за умови зарахування цих коштів у позичку одноосібним власникам ${ }^{68}$. На Півдні України на організацію показових заходів уряд виділяв більше коштів Херсонській губернії. Зокрема, за період 1908-1910 pр. на організацію агрономічної допомоги господарствам Катеринославської губернії було виділено 81655 руб., Таврійської - 91160 руб., Херсонської - 159208 руб. ${ }^{69}$. У 1912 р. найбільшу суму на агрономічну допомогу в регіоні також отримала Херсонська губернія - 271104 руб. ${ }^{70}$.

Крім показових заходів, у роки Столипінської аграрної реформи почала інтенсивно розвиватися й дослідна справа. Спираючись на досвід США, ГУЗі3 було вирішено створити в кожній грунтово-кліматичній області 3 кількох губерній велику обласну дослідну станцію 3 відділами по всіх найважливіших галузях агрономічного дослідження. Згідно з законом від 9 червня 1912 р. було засновано Катеринославську дослідну станцію для дослідження потреб трьох південноукраїнських губерній. На розвиток дослідної справи уряд планував виділяти значні кошти. Зокрема, в 1913 р. було виділено 3 млн. 787 тис. руб., а на 1914 р. було заплановано 4 млн. 587 тис. руб. Але ці асигнування, як і сам розвиток дослідної справи, були на декілька років припинені війною ${ }^{71}$.

Розпочата у 1914 р. Перша світова війна сильно позначилася на обсягах агрономічної допомоги. Землевпорядна й агрономічна діяльність відійшли на другий план, поступившись пріоритетним місцем постачанню армії продовольством, обстеженню сімей мобілізованих, розподілу між ними матеріальної та насіннєвої допомоги тощо $0^{72} .3$ початком війни агрономічна допомога селянським господарствам на Півдні України суттево зменшилася, багато заходів не здійснювалися або не були доведені до кінця.

Отже, Столипінська аграрна реформа внесла суттєві корективи у господарський побут життя селян на Півдні України, що зумовило іх до позитивних змін у ставленні до праці у власному господарстві, його покращенні та підвищенні прибутковості. Незважаючи на недостатнє фінансування урядом розвитку позашкільної сільськогосподарської освіти та показових заходів, усі зусилля земств і сільськогосподарських товариств, спрямовані на аграрне просвітництво селян, дали видимі результати, які виразилися у поліпшенні якості обробки селянських полів, підвищенні врожайності на їхніх ділянках і розвитку нових для них галузей господарства.

У справі просвітницької агрономічної допомоги на Півдні України ще до початку Столипінської аграрної реформи був певний досвід проведення такої роботи земствами, що позитивно вплинуло на хід реформи у регіоні. Бесіди та читання були одним з головних способів поширення сільськогосподарських знань серед дорослого населення. Крім того, вони допомагали встановити комунікацію з селянами і дізнаватись про головні проблеми в їхніх господарствах. Показові заходи на живому прикладі доводили селянам можливість i вигідність застосування на своїх ділянках поліпшених прийомів рільництва та введення багатопільних сівозмін. Зрозуміло, що за такий короткий термін свого існування

\footnotetext{
${ }^{68}$ Россия. Комитет по землеустроительным делам. Краткий очерк за первое десятилетие: 1906-1916. Петроград: Т-во Р. Годике и А. Вильборг, 1916. С. 47-49.

${ }^{69}$ Землеустройство (1907-1910 гг.). С. 88-95.

${ }^{70}$ Кофод К.А. Русское землеустройство. Санкт-Петербург: Тип-фия В.Ф. Киршбаума, 1913. С. 99.

${ }^{71}$ Давыдов М.А. Указ. соч. С. 606-607.

${ }^{72}$ Березняк Я.В. Вказ. пр. С. 74-75.
} 
агрономічна організація не встигла проявити в повному обсязі свою просвітницьку діяльність по відношенню до господарств одноосібного володіння, але просвітницька агрономічна допомога дала можливість одноосібним власникам змінювати колишню систему господарства та переходити до більш вдосконалених прийомів сільськогосподарської техніки.

Iryna Mironova Educational agronomic assistance for the South Ukraine's villagers in early XX century

Abstract: The article reveals the main point of the Stolypin reform's providing in the South of Ukraine - the educational agronomic assistance for villagers, who pass to individual and the holding farm. This assistance was carried out in two ways. The first one is an extra spread of agricultural knowledge among adults and the second is providing of showcase events. The author mentions in the article that those events were not reform's novelties; they were implemented by the zemstvos in the South Ukraine since the end of XIX century which begun the foundation of reform's positive results in the region.

The issue of agricultural education among villagers were solved through the organization of readings and talks on agronomic topics, arrangement of temporary agricultural courses, as well as excursions to exemplary fields and plots. The article determines the role of zemstvo and agricultural communities in setting up and conducting those activities in the region.

The organization of showcase events included creation of exemplary fields and plots sets that had significant support from zemstvos in Kherson and Katerynoslav governorates. The main purpose of those events was showing villagers the possibility to implement improved techniques of farming, horticulture, and animal husbandry on their plots. The author mentions that with the beginning of the First World War educational agronomic assistance significantly decreased.

The article defines that provided activities with educational agronomic assistance for the South Ukraine's villagers established credibility, support, and personal interest. The result of those actions became the application of new improved methods of farming on their own plots and increased yields.

Keywords: South of Ukraine, Stolypin's agrarian reform, educational agronomic assistance, exemplary fields and plots, zemstvo 